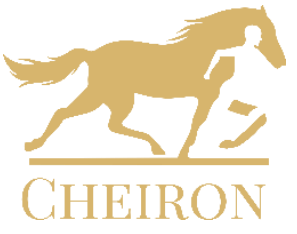

Cheiron: The International Journal of

Equine and Equestrian History

Vol. 1, Issue 1/2021

(C) The Authors 2021

Available online at

http://trivent-publishing.eu/

\title{
Interdisciplinary Approaches to the Medieval Warhorse
}

\author{
Carly Ameen, Gary Paul Baker, Helene Benkert, Camille Vo Van Qui, \\ Robert Webley, Robert Liddiard, Alan K. Outram, Oliver H. Creighton
}

\begin{abstract}
The warhorse is arguably the most characteristic animal of the English Middle Ages. But while the development and military uses of warhorses have been intensively studied by bistorians, the archaeological evidence is too often dispersed, overlooked or undervalued. Instead, we argue that to fully understand the cultural significance and functional role of the medieval warhorse, a systematic study of the full range of archaeological evidence for warhorses (and horses more generally) from medieval England is necessary. This requires engagement with material evidence at a wide variety of scales - from individual artefacts through to excavated assemblages and landscape-wide distributions - dating between the late Saxon and Tudorperiod (c. AD 800-1600). We present here a case study of our interdisciplinary engaged research design focusing upon an important English royal stud site at Odiham in Hampshire. This brings together several fields of study, including (zoo)archaeology, history, landscape survey, and material culture studies to produce new understandings about a beast that was an unmistakable symbol of social status and a decisive weapon on the battlefield.
\end{abstract}

\section{Keywords}

Archaeology; warhorse; material culture; landscape; zooarchaeology; deer park; stud.

\section{DOI: 10.22618/TP.Cheiron.20211.1.233005}

CHEIRON is published by Trivent Publishing

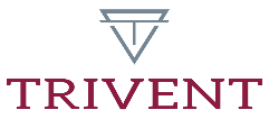

This is an Open Access article distributed in accordance with the Creative Commons Attribution Non Commercial (CCBY-NC-ND 4.0) license, which permits others to copy or share the article, provided original work is properly cited and that this is not done for commercial purposes. Users may not remix, transform, or build upon the material and may not distribute the modified material (bttp:/ / creativecommons.org/ licenses/by-nc/4.0/) 


\title{
Interdisciplinary Approaches to the Medieval Warhorse
}

\author{
Carly Ameen, ${ }^{1}$ Gary Paul Baker, ${ }^{2}$ Helene Benkert, ${ }^{1}$ Camille Vo Van Qui, ${ }^{1,3}$ \\ Robert Webley, ${ }^{1}$ Robert Liddiard, ${ }^{2}$ Alan K. Outram, ${ }^{1}$ Oliver H. Creighton ${ }^{1}$
}

\begin{abstract}
The warhorse is arguably the most characteristic animal of the English Middle Ages. But while the development and military uses of warhorses have been intensively studied by historians, the archaeological evidence is too often dispersed, overlooked or undervalued. Instead, we argue that to fully understand the cultural significance and functional role of the medieval warhorse, a systematic study of the full range of archaeological evidence for warhorses (and horses more generally) from medieval England is necessary. This requires engagement with material evidence at a wide variety of scales - from individual artefacts through to excavated assemblages and landscape-wide distributions - dating between the late Saxon and Tudorperiod (c. AD 800-1600). We present here a case study of our interdisciplinary engaged research design focusing upon an important English royal stud site at Odiham in Hampshire. This brings together several fields of study, including (zoo)archaeology, history, landscape survey, and material culture studies to produce new understandings about a beast that was an unmistakable symbol of social status and a decisive weapon on the battlefield.
\end{abstract}

\section{Keywords}

Archaeology; warhorse; material culture; landscape; zooarchaeology; deer park; stud

\section{Introduction}

The warhorse is the most iconic animal of the English Middle Ages. As distinctive symbols of status, horses were central to the aristocratic image and closely bound up with concepts of knighthood and chivalry. As weapons of war bred for size, strength and stamina, warhorses changed the face of battle. But our established understanding of warhorses is based almost entirely on historical scholarship. In contrast, archaeological evidence, which has immense potential to challenge received wisdom and transform knowledge about an animal so critical to medieval life, remains neglected. Archaeologists have investigated many facets of past horse-human interaction, including funerary rites, dietary influences, iconography and religion and, of course, warfare. In comparison to its counterparts in the prehistoric and Roman periods, the medieval warhorse has received minimal archaeological study. The High Middle Ages in particular are traditionally seen as an "age of cavalry" in Western Europe, during

\footnotetext{
${ }^{1}$ Department of Archaeology, University of Exeter, Laver Building, North Park Road, Exeter, UK.

2 School of History, University of East Anglia, Norwich Research Park, Norwich, UK.

${ }^{3}$ Department of History, University of Exeter, Amory Building, Rennes Drive, Exeter, UK.
} 
which the knight on horseback became the dominant force on the battlefield until at least c. $1300 .{ }^{4}$ Possession of a trained horse was essential to the creation, negotiation and expression of high-status identity: the term "chivalry" is derived from the Old French "chevalerie," which in turn derives from the Latin caballerius ("horseman"). According to historical sources there was no single type of medieval warhorse; instead, a wide range were kept, and these types changed markedly through time as a product of selective breeding, feeding, and training in stud farms to create animals with the strength, endurance and size to give their riders a decisive advantage. Warhorses are well covered in historical scholarship. For example, the sole surviving contemporary treatise on medieval horsemanship has recently been published, ${ }^{5}$ and historians have produced several synthetic studies. ${ }^{6}$ In contrast, the archaeological evidence has been mainly overlooked, despite its richness, diversity, and its capacity to enrich historical narratives through new state-of-the-art methodologies.

The potential of our integrated approach to the medieval horse can be demonstrated through a preliminary analysis of Odiham in Hampshire. Odiham was a major royal manor from the eleventh century, with the royal presence emphasised by King John, who constructed a castle here in the early thirteenth century, superseding an earlier royal residence on a separate site. ${ }^{7}$ The castle served variously as a royal residence, fortress and grand hunting lodge until the early fifteenth century, but equally relevant to the history of equids at Odiham was the presence of the large deer park 700 metres to the east, the parker of which is first mentioned in $1130 .{ }^{8}$

\section{A. Textual evidence for horse management at Odiham}

The surviving historical accounts for equine activity at Odiham are extremely rich. The accounts of the keepers of the king's studs south of the Trent, now enrolled on the Pipe Rolls in the UK National Archives, reveal that Odiham was in many respects the linchpin location of the royal stud network in the south of England from at least the late thirteenth century until the mid-fourteenth century. These equitium regis (king's stud) accounts contain details of the king's elite horses. The accounts, though not surviving for every year, are fullest for the period from the 1290s to the 1360s, and detail the financial receipts and expenses of horse management. There are separate accounts for the keepers of the studs north and south of the River Trent respectively, and further accounts for the keepers of the king's "great horses" (a

\footnotetext{
${ }^{4}$ Lynn Townsend White, Medieval Technology and Social Change (Oxford: Oxford University Press 1964). Stephen Morillo, "The "Age of Cavalry' Revisited," in The Circle of War in the Middle Ages: Essays on Medieval Military and Naval History, ed. Donald J. Kagay and L. J. Andrew Villalon (Woodbridge: Boydell, 1999), 45-58.

${ }^{5}$ Jeffrey L. Forgeng, The Book of Horsemanship by Duarte I of Portugal (translation) (Woodbridge: Boydell \& Brewer, 2016).

${ }^{6}$ Andrew Ayton, Knights and Warhorses: Military Service and the English Aristocracy Under Edward III (Woodbridge: Boydell \& Brewer, 1999). Ralph H. C. Davis, The Medieval Warhorse: Origin, Development and Redevelopment (London: Thames and Hudson, 1989). Peter Edwards, Karl A. E. Enenkel, and Elspeth Graham, The Horse as Cultural Icon: The Real and the Symbolic Horse in the Early Modern World. Intersections, Volume 18 (Leiden and Boston: Brill, 2011). Charles Gladitz, Horse Breeding in the Medieval World (Dublin and Portland: Four Courts Press, 1997). Ann Hyland, The Medieval Warborse: From Byzantium to the Crusades (Stroud: Sutton, 1994). Philip Sidnell, Warborse: Cavalry in Ancient Warfare (London: Hambledon Continuum, 2006).

7 Graham Brown, "Odiham Castle, Hampshire," Series AI/17, English Heritage Archaeological Investigation Report (2004).

${ }^{8}$ Judith A. Green, "The Great Roll of the Pipe for the 31 Year of the Reign of Henry I, Michaelmas 1130,” Pipe Roll Society New Series 57 (2012): 29.
} 
catch-all term applied largely to adult male destriers and coursers) in the same two jurisdictions. ${ }^{9}$ The majority of the studs were south of the Trent, and the most consistently used in southern England, besides Odiham, were at Cornbury, Woodstock (Oxon.), Hamstead Marshall, Stratfield Mortimer, Windsor (Berks.), Rayleigh (Essex) and Risborough $^{10}$ (Bucks.) (Fig. 1). Each stud primarily consisted of mares and foals, the latter of which were accounted for by age from newborns up to c. 3 yrs old. Upon reaching maturity, at between $2 \frac{1}{2}-3 \frac{1}{2} 2 \mathrm{yrs}$ old, the fillies were either kept within the royal stud network as breeding mares, requisitioned for other purposes within the royal household, or sold. The life journey of the colts within the royal network were slightly different. Shortly after they had been weaned at around $1 \mathrm{yr}$ old the colts from the various southern studs were all sent to Odiham.

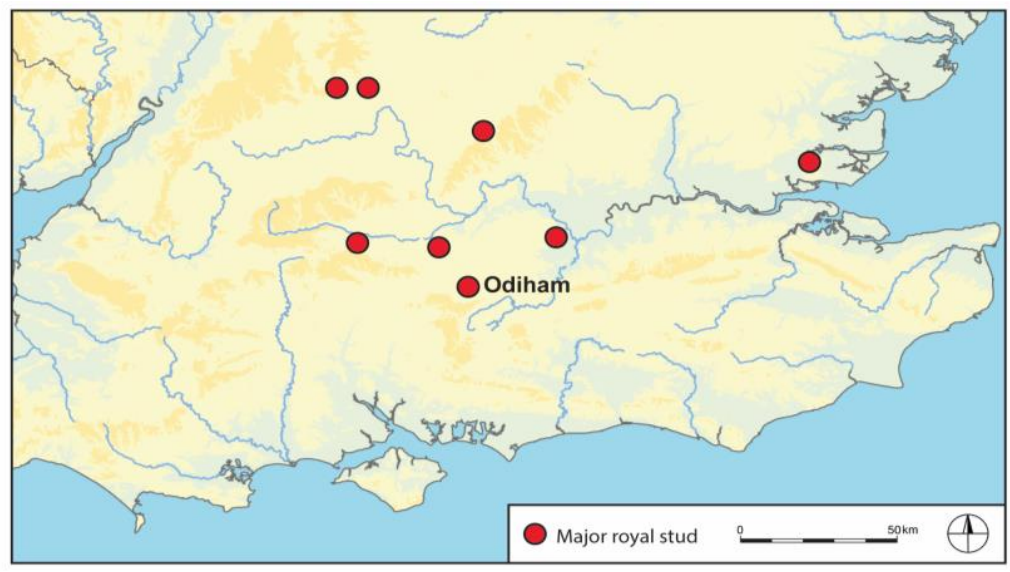

Fig. 1. Distribution map showing major fourteenth-century royal stud sites in southern England

This is what makes Odiham unique within the network. It was not a "stud" in the traditional sense as "an establishment in which stallions and mares are kept for breeding." 11 In the entire history of Odiham's use as a royal stable from at least 1294 until its decommission in 1361, barring the odd instance, no stallions or mares were kept in the royal stables; the site was used exclusively for colts. ${ }^{12}$ As no horse breeding took place at Odiham itself the number of colts was entirely dependent upon those received annually from the

\footnotetext{
${ }^{9}$ This is a simplified summary of what was in reality a more fluid organisational structure. The complete organisational history of the royal equine administration has yet to be written, but for a basic overview in the fourteenth century see H. J. Hewitt, The Horse in Medieval England (London: J. A. Allen and Co., 1983), 12-18.

${ }^{10}$ Known as Risborough or "Great Risborough" in this period, and as Prince's Risborough from at least the fifteenth century: "Parishes: Princes Risborough," in A History of the County of Buckingham: Volume 2, ed. William Page (London: A. Constable, 1908), 260-267, British History Online, www.british-history. ac.uk/vch/bucks/vol2/pp260-267, accessed February 8, 2021.

11 "stud, n.2 and adj.," OED Online (Oxford: Oxford University Press, 2020), www.oed.com/view /Entry/192047, accessed February 8, 2021.

12 [T] he [N]ational [A]rchives E 372/169 mm. 54r-55v (for 1318-21 and 1322-23), are the only mentions of horses other than colts within the royal network at Odiham, and then only for a handful of months in those years.
} 
southern stud network into Odiham, sent by the keeper(s) of the various southern studs. Between 29 September 1345 and 29 September 1346, for example, the keeper at Odiham, William de Ferrour, received a total of 15 colts: 6 from Cornbury, 5 from Stratfield Mortimer, 3 from Windsor, and 1 from Woodstock. ${ }^{13}$ The number of colts thus fluctuated with the size of the southern stud population, itself affected by factors such as outbreak of disease and periodic breeding programmes, not to mention deaths of animals at Odiham. As well as the overall totals of the horses at the start and end of the accounting period, a detailed record was made of the fluctuating totals of the horses present throughout the year (Fig. 2), which included recording of the colts' ages and coat colours.

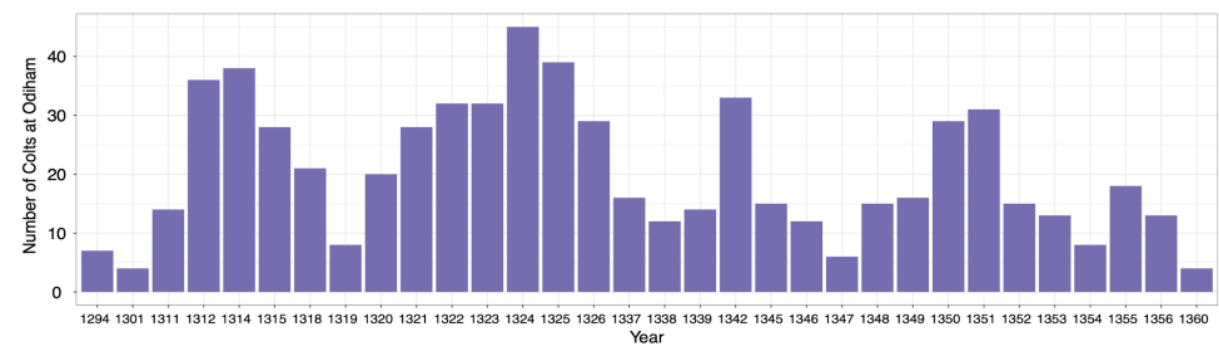

Fig. 2. Number of colts at Odiham around Michaelmas (29 September), 1294-136014

Though the reason for separating these young colts at Odiham away from the other horses in the stud network is not explicitly stated in the accounts, we can surmise that it was done for two principal reasons. First is the fact that these colts were bred specifically for the purpose of maturing into warhorses, to be ridden in combat. By keeping the colts separate from the rest of the herd and together at a single site, their innate aggressive tendencies were fostered while simultaneously strengthening their mental and emotional abilities. ${ }^{15}$ Second, it allowed some basic training of the colts to be undertaken. Though there is little direct evidence for the training of horses in medieval England, information on training can be found in hippiatric treatises such as Jordanus Rufus's De Medicina Equorum (1250) which, from the thirteenth century onwards, circulated across Western Europe ${ }^{16}$ and which likely reflected contemporary practice. ${ }^{17}$ The training method Rufus advocated in this veterinary treatise states that colts should ideally be weaned aged two and kept in bachelor herds. They were then captured aged two or three. Some initial training was undertaken: they were habituated

13 TNA E 372/191 m. 51r.

14 TNA E 101/97/25; E 101/98/15; E 101/99/9; E 101/99/14; E 101/99/22 m. 3; E101/99/23 m. 2; E 372/169 mm. 54r-55v; E 372/170 m. 46r; E 372/172 m. 43r; E 372/182 m. 42v; E 372/183 m. 52r; E 372/184 m. 47r; E 372/187 m. 49v; E 372/190 m. 38v; E 372/191 mm. 51r-51v; E 372/193 m. 30v; E 372/195 m. 43v; E372/195 m. 40v; E 372/196 m. 46v; E 372/198 mm. 42r-42v; E 372/199 m. $37 \mathrm{v}$; E 372/204 mm. 32v, 34v; E 372/208 mm. 39r-39v.

15 Debbie Busby and Catrin Rutland, The Horse. A Natural History (Brighton: Ivy Press, 2019).

16 While there is no direct evidence that Rufus's text circulated in medieval England, and no known translation in Middle English, there are nine known French versions of the treatise, the earliest dating to the thirteenth century, and the treatise was reused by several hippiatric authors across Western Europe. Because it deals with horse husbandry as well as veterinary medicine, the De medicina equorum is an invaluable source to explore what was happening at Odiham, which was probably similar to other studs throughout Western Europe during the medieval period.

${ }^{17}$ Jennifer Jobst, "Practical Advice on Equine Care from Jordanus Rufus, c. 1250 CE," in The Materiality of the Horse, ed. Miriam A. Bibby and Brian G. Scott (Budapest: Trivent Publishing, 2020), 37-69. 
to wear a halter and to be touched all over their body, in preparation for wearing equipment and carrying a rider. They were also desensitised to having their feet handled, in preparation for shoeing, and taught to lead, by following an older horse. ${ }^{18}$ It is almost certain that this rudimentary handling was undertaken at Odiham.

It is not clear if and when the colts within the royal network were gelded. The English may have adopted the contemporary strangulation method of castration practiced by the Teutonic Order on their lands in central and eastern Europe, which renders colts infertile without reducing the aggression derived from the testosterone in their system that is not present if the testicles are removed ${ }^{19}$. It may be that the colts were simply left uncastrated: the thirteenth-century author Albertus Magnus, for instance, recommended that destriers should remain stallions as that would make them less timid on the battlefield ${ }^{20}$. While Jordanus Rufus does not mention castration in his description of the handling and training of a young warhorse, within the Order, castration happened at around 3yrs old, just as the colts were reaching maturity. It may be entirely coincidental that at Odiham this was the age at which colts entered the world of adult horses. Between $2 \frac{1}{2}$ and $3^{1 / 2}$ yrs old the colts at Odiham were inspected by the king's officials. Any deemed 'weak' were sold, as was the case with four colts in November 1351, though by what criteria the inspectors judged the animals is not stated. ${ }^{21}$ The remaining colts were then sent into the custody of the keeper of the king's great horses south of the Trent where they were broken in amongst the king's adult great horses. It was here that their training, amongst the mature stallions of the royal stock, began in earnest. It was presumably also at this point that select colts were chosen as stud horses, like the shiny black colt of $2 \frac{1}{2}$ years old which was sent to Risborough from Odiham in November 1320 after being selected to cover the mares. ${ }^{22}$ Unfortunately, there is no mention of the desired physical characteristics and/or temperaments targeted in colts chosen to be stud stallions nor those destined to become warhorses.

As well as recording the number of animals present in their custody, the keepers' accounts at Odiham and elsewhere also detail the receipts and expenses incurred in managing the horses. For expenditure, the largest cost in the accounts was always for feeding the horses, with large quantities of food purchased and transported to the stud from the local area. There

${ }^{18}$ Jordanus Rufus, Jordani Ruffi Calabriensis Hippiatria, ed. Hieronymus Molin (Padua: Typis Seminarii Patavini, 1818), 4-5: "assero tamen quod si in sufficientibus pascuis usque ad aetatem trium annorum equus libertatem haberet per bona pascua sine societate jumentorum melius et salubrius foret equo (...). Ipso autem capto, ut dictum est, et in capite posito capistro forte de canape ad societatem alicujus equi domati conducatur ad locum, ubi domari debet (...); ita quod ad plenum et secure membra sua circum circa tangantur, et specialiter pedes securius et saepius elevando admodim ferrandi pedes percutiendo" II say however, that if the horse is granted freedom in sufficient pastures until he is three years old, without the company of mares, he will become better and healthier (...). When he has been captured, as has been described, and a strong halter of hemp has been put on his head, he is lead, in the company of a tame horse, to the place where he will tamed (...); so that his limbs can be touched everywhere, safely and completely, and especially his feet which must be lifted and struck, as if they were being shod]. Translation here and elsewhere, unless otherwise specified, are by the authors.

${ }^{19}$ Sven Ekdahl, "Horses and Crossbows: Two Important Warfare Advantages of the Teutonic Order in Prussia," The Military Orders 2 (1998): 119-51.

20 Albertus Magnus, De Animalibus libri XXVI nach Cölner Urshrift, ed. Herman Stadler (Munster: Aschendorff, 1920), 1378: "bellicorum autem equorum est non castrari quia ex castratione efficuntur timidi" [warhorses are not castrated, because the castration makes them timid].

21 TNA E 372/198 m. 42r. The word used is the Latin recronio which means "old animal weeded out of flock." R. E. Latham, Revised Medieval Latin Word-List from British and Irish Sources (London: Oxford University Press, 1973), 395.

22 TNA E 372/169 m. 54v. 
were also the wages of the grooms and keepers, ${ }^{23}$ as well as other, occasional, miscellaneous payments for tasks like shoeing horses and medical treatment. Taking the account of William de Ferrour, keeper of the horses at Odiham in the accounting year 1348-49 as an illustrative example ${ }^{24}$, we see that William received a total of $f 282 \mathrm{~s} 11^{1 / 2} \mathrm{~d}$ for the upkeep of 32 colts at various points of the year ${ }^{25}$. Of this income, the lion's share - $f^{2} 2111 / 2 \mathrm{~d}$ - came from Henry Sturmy, Sheriff of Hampshire. The remaining 2s came from the sale of the hides of three colts which had died during the course of the accounting period. It is this practice of selling the hides of deceased animals, likely to artisans such as tanners, which explains why the remains of medieval horses are relatively rare in the archaeological record at elite sites ${ }^{26}$. In the same year William's expenses totalled $f 2719 \mathrm{~s} 11 \frac{1}{2} \mathrm{~d}$ : $f, 819$ s for hay purchased from the sheriff of Hampshire; $f 10$ 10s $2 \mathrm{~d}$ for 164 quarters of oats from 'diverse parks'; 21s for straw; $43 \mathrm{~s} 4 \mathrm{~d}$ for the carriage of said fodder from various locations to Odiham; and 106s 51/2d for the wages of the keeper and one groom looking after the horses.

\section{B. Horses in the medieval Hampshire landscape}

The park at Odiham was a large oval-shaped area that would have comprised a mixture of woodland and open grazing, augmented in this case by meadow along the floodplain of the River Whitewater, which flowed east through the park and divided it in two (Fig. 3). The park's primary purpose was to keep deer for royal hunting activities, but it also served as a grazing area for a variety of stock, of which horses were particularly important. The earliest specific documentary reference to horses within the park is in 1224 when it housed those of the constable. ${ }^{27}$ By the 1260 s it was pastured by colts, with their keeper - Robert - described as the colterio charged with their care. ${ }^{28}$ This reference specifically to colts is significant and pre-dates the use of the park in the later thirteenth and fourteenth centuries when Odiham came to occupy its crucial place in the royal stud network.

Why Odiham should have been chosen as the location for the rearing of colts can perhaps be related to the wider geography. Most obviously, it lay in the part of the kingdom where the majority of other royal studs were located and so was undoubtedly a convenient place in which to draw together the juvenile stock from elsewhere in the network (Fig. 1). But it is also worth speculating that there was more than convenience at work. Odiham park was slightly unusual in being bisected by a large watercourse and it is conceivable that the grazing and fodder provided by the chalk stream of the Whitewater was prized in the Middle Ages

\footnotetext{
${ }^{23}$ The number of officials managing the horses varied over time. The keeper was always present, if not in person then at least via a deputy. For the grooms the usual practice for colts was that each groom managed several animals. From April 1295 to September 1296, for instance, two grooms were assigned to sixteen colts (thus eight each), but there does not seem to be any particular ratio of grooms to horses, and ordinarily it was much less than 1:8. Each groom in this instance received $2 \mathrm{~d}$ per day in wages (TNA E 101/97/28). The keeper's daily rate is not stated in this instance, but a later document for 1314-15 gives it as 12d daily (TNA E101/99/16 m. 4).

24 The accounting year ran from 30 September in the first year to 29 September the following year.

25 TNA E $372 / 195 \mathrm{~m} .43 \mathrm{v}$. The total colts at the start of the account was 15 , with 16 at the end, though 32 horses were accounted for in all with the receipt and disbursement of horses during the year.

${ }^{26}$ Richard Thomas and Martin Lacock, "Food for the Dogs? The Consumption of Horseflesh at Dudley Castle in the Eighteenth Century," Environmental Archaeology 5 (2000): 83-91.

${ }^{27}$ Thomas Duffus Hardy, Rotuli Litterarum Clausarum in Turri Londinensi Asservati: 1224-1227 (London: G. Eyre and A. Spottiswoode, 1833), 1-585.

${ }^{28}$ Louise J. Wilkinson, The Household Roll of Eleanor de Montfort, Countess of Leicester and Pembroke, 1265, British Library Additional MS 8877, The Pipe Roll Society New Series Lxiii (Woodbridge: The Boydell Press, 2020), 98.
} 
for its richness in calcium. Calcium is a crucial nutrient for normal bone growth and in particular young horses as well as broodmares require a calcium-rich diet to build up and maintain strong skeletal support. ${ }^{29,30}$ The records of the royal studs are full of information on the foodstuffs provided for medieval horses. The majority of the royal studs were within, or adjacent to, royal parks and manors where the horses were often pastured and grazed in the spring and summer months. In the winter the horses were provided with the majority of their fodder by the royal grooms and keepers: oats, hay, straw, and cut grass, with smaller quantities of other foodstuffs like bran, beans, peas, and "horsebread," a mixture of ground grains and legumes. ${ }^{31}$

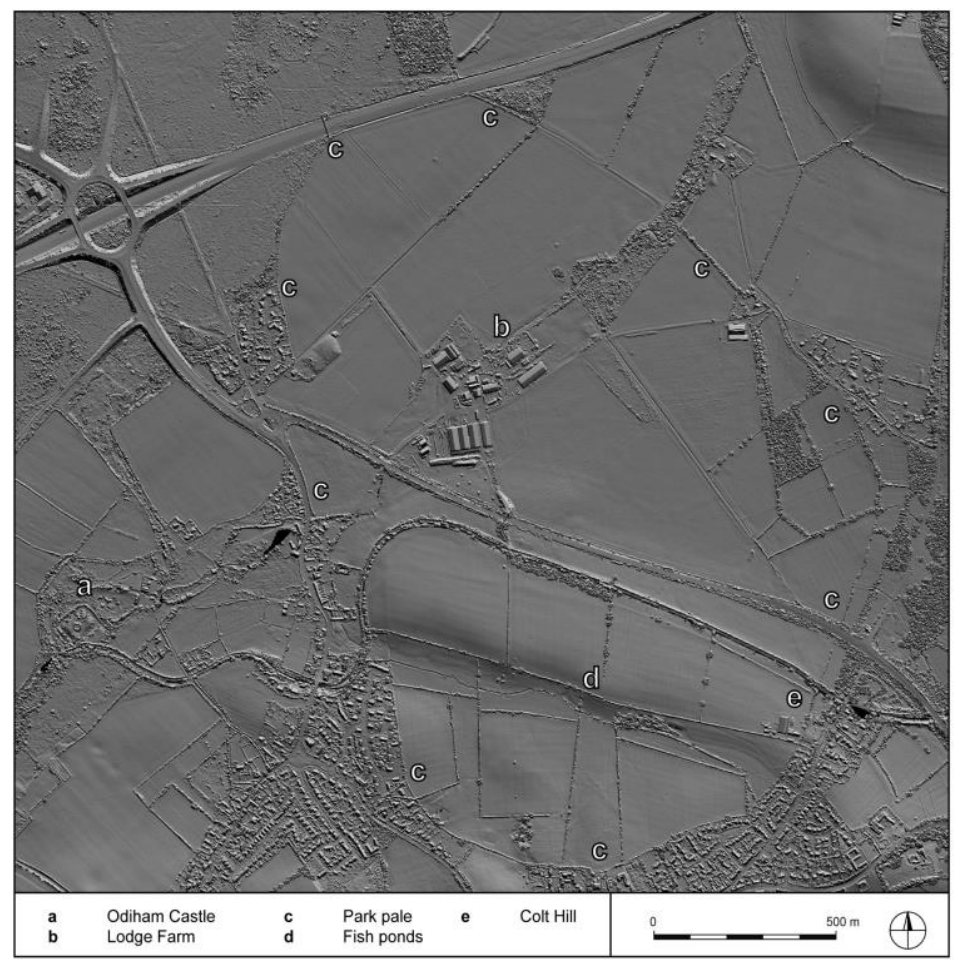

Fig. 3. Site plan of Odiham, highlighting the location of the castle, deer park and other key features. (LiDAR C Environment Agency 2015. All rights reserved)

This diet, rich in various vitamins and minerals, was required in vast quantities to meet the calorific needs of the king's horses. ${ }^{32}$ Beyond ideal access to pasture and nutrition, the

\footnotetext{
${ }^{29}$ H. F. Hintz, "Mineral requirements of the horse: A historical perspective," Proceedings of short course on equine nutrition (Kentucky Equine Research, 1996).

${ }^{30}$ Sarah Pilliner, Horse Nutrition and Feeding (Oxford: Blackwell Scientific Publications, 1992).

${ }^{31}$ For illustrative examples see: Michael Prestwich, "Big and Beautiful'. Destriers in Edward I's Armies," in Military Communities in Late Medieval England: Essays in Honour of Andrew Ayton, ed. Gary Paul Baker, Craig Lambert, and David Simpkin (Woodbridge: The Boydell Press, 2018), 4-7.

${ }^{2}$ On these nutritional needs see: Katrin Boniface, "Bread for my Horses," in The Horse in Premodern European Culture, ed. Anastasija Ropa and Timothy Dawson (Berlin: De Gruyter, 2019), 161-173.
} 
presence of the watercourse at Odiham could have allowed the colts to naturally benefit from hydrotherapy treatments. Veterinary treatises such as the De Medicina Equorum highlighted the advantages of horses standing daily in running water, as it was believed that this would stop bad humours from descending to the legs, ${ }^{33}$ a practice which continues to be used today in modern horses to alleviate inflammation. ${ }^{34}$

Long-term use of Odiham for the management of colts is reflected in the modern placename "Colt Hill" on the south-east side of the park (Fig. 3). Such "colt" names are not particularly common, and so in this case it is perhaps the best guide to the location of actual hooves on the ground. Despite the difficulty in locating the physical remains of the stud, historical records for the maintenance of stables and stud buildings appear sporadically in the records, notably when repairs were required. It seems that, even though the "stud" at Odiham was within the royal manorial bounds, there was a clear distinction between the royal officials whose responsibility it was to pay for this maintenance. Anything that was classed as being "of the stud" came under the keeper of the horse's remit, and everything else equine related in the manor came under the jurisdiction of the clerk of the king's works. In 1324-25, for example, the keeper at Odiham, John de Redemere, paid to repair a wall in the colt house of the "stud," whereas two years earlier John de St John, keeper of the castle and manor of Odiham in 1322-23, accounted for a shingler and his assistant for 30 days to make shingles and repair the roof of the great stable within the castle. ${ }^{35}$ Similarly, at some point between 1366 and 1371 Richard Bernard, clerk of the king's works at Odiham, paid 14s 10d to repair the "long stable," which may have been the same structure as the "great stable" from forty years before. This included payments for three carpenters, a tiler, a cooper, a plasterer/whitewasher, and nine labourers; these latter repairs occurred at least five years after Odiham had ceased to operate as a royal "stud" in $1361 . .^{36}$

Of course, as a royal residence and manor house, the king's colts were not the only horses kept at the site. The account of John de St John for 19 September 1322 to 5 May 1323, for example, reveals that the manor possessed five male farm horses, five mares (a sixth died), and eleven foals of which two died. ${ }^{37}$ Indeed, horses were not the only animals on the manorial estate, with both historical and zooarchaeological evidence suggesting a diverse assemblage of animals used for both food and work present at Odiham alongside the farm horses and the colts from the royal stud. ${ }^{38}$ St John's account again provides numbers and types of animals on the manorial estates, with oxen (a total of 49 accounted for during the

\footnotetext{
${ }^{33}$ Rufus, Calabriensis, 6: "teneatur tantum in aque, tam in mane quam in sero, usque ad genua (...) in aquam velocem dulcem, frigidam vel marina, eo quod frigidas aquae dulcis vel siccitas aquae marinae naturaliter equi crura desiccant coarctando humores et aegritudines descendentes ad crura" the must be held in the water, in the morning and in the evening, up to his knees, in running fresh water or in sea water, for the coldness of fresh water or the dryness of sea water desiccates and contracts the humours and infirmities that would move down to the legs]. This recommendation implies that the stud where the future warhorses are kept and trained should be located near either a river or the sea. Recent research into the benefits of hydrotherapy for horses has shown the benefits it can have on recovery from injury. See Melissa R. King, "Principles and Application of Hydrotherapy for Equine Athletes," The Veterinary Clinics of North America: Equine Practice 32 (1) (2016): 115-126.

${ }^{34}$ King, "Principles and Application of Hydrotherapy," 115-26.

35 TNA E 372/170 m. 46r (Redemere). The payment was for 3s $10 \mathrm{~d}$, but it also included the expense of paying a cooper to repair the roof in the mare's house at Rayleigh. E 372/168 m. 38r (St John).

36 TNA E $101 / 478 / 28 \mathrm{~m} .9$.

${ }^{37}$ E $372 / 168$ m. 38r.

${ }^{38}$ David Allen and Nick Stoodley, "Odiham Castle, Hampshire: Excavations 1981-85," Proc. Hampshire Field Club Archaeol. Soc 65 (2010): 23-101.
} 
account, suggesting they bore the brunt of the agricultural workload), bullocks, cows, heifers, bovine calves, sheep and goats of various ages and sexes, a boar, and four swans; around 400 animals in total, not including the farm horses and the colts from the royal stud.

\section{Physical evidence for horses at Odiham}

In contrast to the rich historical records surrounding the operation of a significant royal stud at Odiham, the zooarchaeological record presents rather limited evidence for the horses themselves. During excavations in the 1980s, among a substantial faunal assemblage, a few horse bones were recovered, described by Sheila Hamilton-Dyer as at least three, and potentially four equids, from two areas of the site. ${ }^{39}$ Primarily, in gully 37 are the remains of two (possibly three) partially articulated horses, consisting of two sets of crania and a series of vertebrae and ribs, alongside an isolated metatarsal and pelvis, which may or may not be associated with one of the more complete skeletons. The most complete horse's cranium shows a lack of canine teeth in both the upper and lower jaws suggesting it was female. Hamilton-Dyer also reports extensive spinal pathologies, indicating that the spine's lumbar area would have been totally inflexible. ${ }^{40,41}$ Modern parallels have been reported, almost always in the domestic horse rather than wild equids or donkeys. ${ }^{42}$ While the appearance of the pathologies seems severe, in life they likely would have amounted to no more than stiffness in the lumbar region. This would not have prevented use of the animal for draught or pack purpose, but would have likely prohibited the range required for a riding animal. This horse was approximately 10-12 years old when it died, and its mandible shows indication of diastema exostosis, likely from wearing a bit. ${ }^{43}$ The other semi-articulated skeleton is a horse of approximately seven years, and likely male given the presence of canine teeth. Small knife cuts consistent with skinning are present across the nasal and near the eye socket, where the skin is attached closely to the bone. The mare was directly radiocarbon dated to between AD 1040-1210 (914 \pm 29 uncal. BP; SUERC-93557). The early range of this date is interesting, given construction of the castle did not begin until 1207 AD. There is documentary evidence for a mill located at or near the site, which was demolished to make way for the castle, ${ }^{44}$ but the association of the horse remains with projectiles from siege engines within what excavating archaeologists define as a defensive ditch (Fig. 4), suggest this specimen comes from the earliest castle occupation at the start of the thirteenth century. It is even possible these horses were present at, and potentially a casualty of, the 1216 siege, ${ }^{45}$ though it is unlikely that either was used specifically in combat, particularly the mare. While this date falls

\footnotetext{
${ }^{39}$ Sheila Hamilton-Dyer, “Animal Bone," in Allen and Stoodley (2010): 75-98.

${ }^{40}$ László Bartosiewicz and Gábor Bartosiewicz, “"Bamboo Spine’ in a Migration Period Horse from Hungary," Journal of Archaeological Science 29(8) (2002): 819-30.

${ }^{41}$ Nemanja, Marković, Maciej Janeczek, Darko Marinković, Oliver Stevanović, Nikola Krstić, Katarina Petrujkić, and Ružica Trailović, "Paleopathological and Radiological Examination of the Avar Period Horse Bones from Central Balkans (Serbia)," Med. Weter 71(10) (2015): 619-625.

42 Olof Dietz and Bernhard Huskamp, Handbuch Pferdepraxis (Stuttgart: Enke Verlag, 2006).

${ }^{43}$ Robin Bendrey, "New Methods for the Identification of Evidence for Bitting on Horse Remains from Archaeological Sites," Journal of Archaeological Science 34(7) (2002): 1036-50.

${ }^{44}$ Calendar of Charter Rolls (1226-57), p. 209. London, HMSO, 1908.

${ }^{45}$ Catherine Hanley, Louis: The French Prince Who Invaded England (New Haven: Yale University Press, 2016).
} 
slightly outside the range of the analyses, a plateau along the calibration curve makes this period of the early second millennia AD difficult to date with more precise accuracy. ${ }^{46}$

Withers height $(\mathrm{WH})$ estimates ${ }^{47}$ from two complete long bones suggest one of the equids in gully 37 was a horse of approximately $13 \mathrm{hh}(1.34 \mathrm{~m})$, though whether this was the mare, the male horse, or a third horse cannot be determined due to post-excavation processes. The tibia found in layer 6 from a fourth equid, likely comes from a donkey, estimated at 10hh $(1.09 \mathrm{~m})$. For the horse, a height of approximately 13 hands is typical for the medieval period. ${ }^{48}$ The bones of all equids suggest mature, but not old animals, in contrast to the historical record which suggests that primarily colts were kept on site, and mature horses of both sexes would have been used for agricultural purposes at the site. Horses may die (or be killed) for a variety of reasons and disposal in ditches is very common in archaeological contexts. The marks on the skull of the male horse indicate both skinning and gnawing, suggesting that the animal had been skinned and was left accessible to dogs before finally ending up in the gully. A similar, and larger, group of partial carcasses was recovered from a fourteenth-century gully at Jenning's Yard, Windsor ${ }^{49}$ with evidence for similar taphonomic processes, indicating that a knacker or fellmonger made use of the hides prior to deposition. We know from the historical records mentioned above that colts which died were also sold for their skins, indicating that preferential treatment of the royal colts likely ended at death.
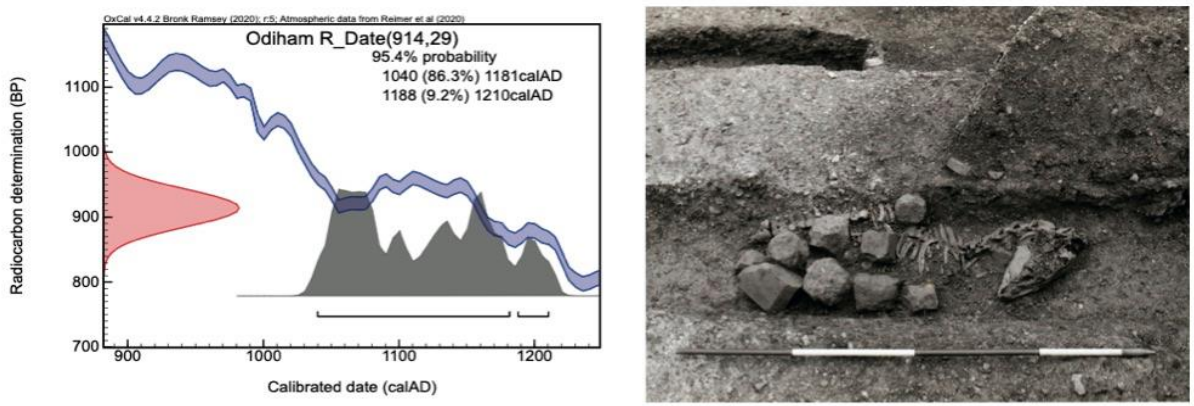

Fig. 4. Calibrated radiocarbon curve (left) for the mare found in gully 37 with projectiles (right) (with thanks to Hampshire Field Club)

Our review of the zooarchaeological evidence suggests that these horses were ones used in the daily domestic activities of the manor and royal residence, and were unlikely to be associated with the stud itself. A reassessment of the horse bones from Odiham would considerably enhance our understanding of the role that adult horses played at the site during this period. In particular, the need for clarity around the nature and extent of the pathologies

\footnotetext{
46 Alex Bayliss, Peter Marshall, Michael W. Dee, Michael Friedrich, Timothy J. Heaton, and Lukas Wacker, "IntCal20 Tree Rings: An Archaeological Swot Analysis," Radiocarbon 62 (4) 2020: 1045-78.

${ }^{47}$ Ludwig Kiesewalter, Skelettmessungen Am Pferde: Als Beitrag Zur Theoret. Grundlage Der Beurteilungslehre Des Pferdes (Leipzig: Druck v. G. Reusche, 1888).

${ }^{48}$ Richard Thomas, Matilda Holmes, James Morris, and Emily Abrehart, “"The Brede of Good \& Strong Horsis': Zooarchaeological Evidence for Size Change in Horses from Early Modern London," PostMedieval Archaeology 52(2) (2018): 224-38.

${ }^{49} \mathrm{John}$ W. Hawkes and Michael J. Heaton, Closed-Shaft Garderobe and Associated Medieval Structures at Jennings Yard, Windsor, Berkshire, Wessex Archaeology Reports, No. 3. (Salisbury: Trust for Wessex Archaeology, 1993).
} 
noted by Hamilton-Dyer is needed. From the currently available evidence, it is not clear if the mare suffered from "bamboo spine" (spondylosis ankylopoetica) ${ }^{50}$ which is an inherited condition, or spondylosis chronica deformans, as documented in other archaeological populations and likely caused by the intensity and duration of in-life activity. A further analysis of the severity of the diastema would highlight the extent of bit use, and thus potentially on the longterm use of the animals for work. Together, these new data would not only provide a better understanding of the life of horses at Odiham, but a thorough catalogue of observed equid pathologies can then be used to aid the assessment of other archaeological equids. Furthermore, advances in metric and morphometric techniques will allow for the examination of detailed morphological variation from the long bones recovered at Odiham. In combination these biological datasets can provide much needed detail on the diversity of medieval horses that is not captured by size measurements and withers height estimates alone.

\section{Equine artefacts from Odiham Castle and immediate environs}

The report of the 1980 s castle excavations ${ }^{51}$ documented only four items of equestrian equipment. These are discussed below; one is discounted, but a new item is put forward (Fig. 5). An absence of fiddle key nail heads from horseshoes (compare 64 examples of [nail] Types $11-13$ at Ludgershall Castle, Wiltshire, ${ }^{52}$ suggests that the excavators did not work in the area of the stables documented in the Pipe Rolls for 1212-14, whose location was suggested to have been in one of the wards.
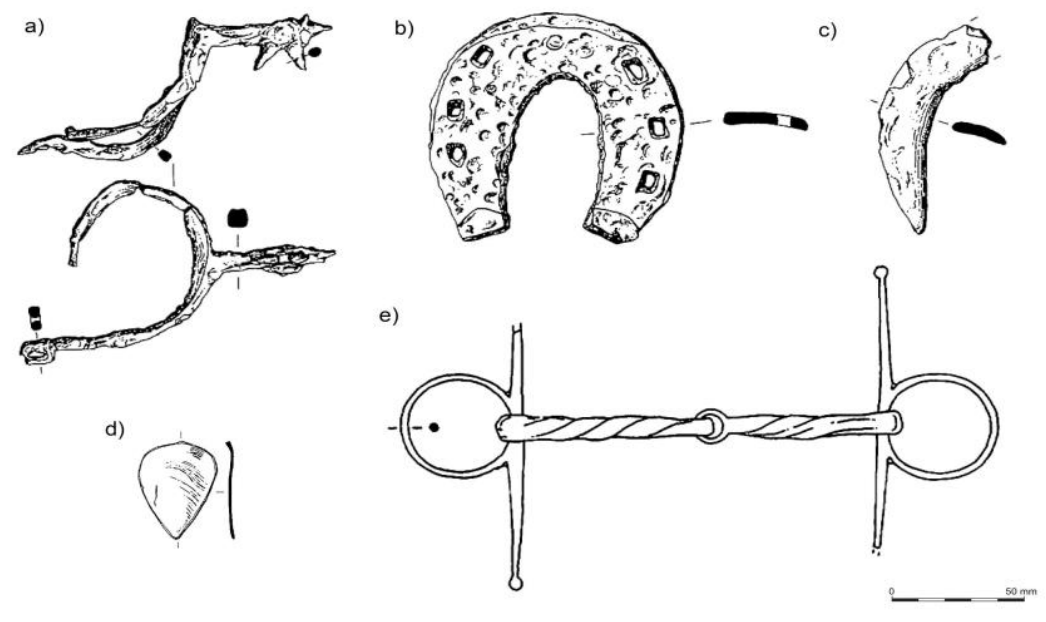

Fig. 5. Equine artefacts from excavations at Odiham Castle in the 1980s (with thanks to Hampshire Field Club): a) prick spur; b) horseshoe; c) probable horseshoe;

d) probable harness pendant; e) snaffle bit.

\footnotetext{
${ }^{50}$ Bartosiewicz and Bartosiewicz, "'Bamboo Spine,", 819-30.

51 Allen and Stoodley, “Odiham Castle, Hampshire: Excavations 1981-85," 23-101.

52 Tom MacNeill, "The iron nails," in Ludgershall Castle: a report on the excavations by Peter Addyman 19641972, ed. Peter Ellis (Devizes: Wiltshire Archaeological and Natural History Society, 2000), 229, Table 15.
} 
A spur was described in the site report, dating to c. 1265-1350 from its context ${ }^{53}$ (Fig. 5a). It has a small, six-pointed rowel, a short neck, subtle crest, and one, rectangular, terminal loop extant. The terminal, of Ward Perkins type D, suggests that this is a spur for a right foot. This terminal type is known from the advent of the rowel spur, around the second quarter of the thirteenth century onwards, ${ }^{54}$ though it ceased being popular around the middle of the fourteenth century. ${ }^{55}$ This spur's characteristics are all present on a spur found in London, which Blanche Ellis dated to c. 1260-1320. Such dating is not inconsistent with the late thirteenth- to fourteenth-century date suggested in the site report, ${ }^{56}$ but offers a tighter range and earlier end date; it is also entirely consistent with the context dating.

From a later context, a horseshoe was recovered in the foundation for Building IV, dating to c. $1350-1500^{57}$ (Fig. 5b). Although the rectangular nail holes were described in the site report as "countersunk," it would appear that they simply taper around each perforation. This characteristic, alongside the broad web noted $(34 \mathrm{~mm})$, and the angular inner profile of the horseshoe, suggests classification as Clark type $4 .{ }^{58}$ In London, type 4 shoes appear in contexts from c. 1270 onwards, becoming the dominant form in the second quarter of the fourteenth century. The shoe was described as "small" - the width, extrapolated from the scale drawing, is c. $97 \mathrm{~mm}$ - and it would rank among the smallest type 4 shoes known from London. Estimates of horses' heights as extrapolated from shoe dimensions have only been cautiously essayed in the literature. Based on such work as has been conducted, a WH in the region of 12-13 hands may be suggested here, one consistent with the estimated height of the horse whose skeleton was found in gully 37 (described above). A second possible horseshoe was recovered, but has no phasing or locational data apparent. This is plausibly another Clark type 4 horseshoe with a "feather-edged" (tapering) heel. Rather than being "wavy edge[d]" and lacking nail holes it might be that the indentations at the outer edge are the holes, broken through (Fig. 5c).

Though not originally described as such, our review of the material suggests a copperalloy "leaf-shaped fragment" (Fig. 5d) is consistent with a harness pendant, with indications of a broken suspension loop at the top. As a harness pendant, the form may be classified as Krabath's Variente 4400 (pointed oval), but may also be conceived of as a kite-shaped shield. The relatively shallow curve at the top suggests an inspiration from shields of the twelfth century, ${ }^{59}$ before they came to be superseded by triangular shields in the first quarter of the thirteenth century. ${ }^{60}$ The form's main dating evidence from England comes from Barnard Castle (Co. Durham), where a similar pendant was found in a thirteenth-century context. ${ }^{61}$

\footnotetext{
53 Allen and Stoodley, “Odiham Castle, Hampshire: Excavations 1981-85,” 63-64; fig. 22, no. 11.

54 John Ward Perkins, London Museum: Medieval catalogue (London: HMSO, 1967 [1940]), 99.

55 Blanche M. A. Ellis, "Spurs and spur fitting," in The medieval horse and its equipment c.1150-c.1450. Medieval finds from excavations in London 5, ed. John Clark (New edition, First published 1995, London: H.M.S.O.; Woodbridge: Boydell Press, 2004 [1995]), fig. 97, no. 328.

${ }^{56}$ Nick Stoodley, "Metalwork," in Allen and Stoodley (2010), 63.

57 Allen and Stoodley, “Odiham Castle, Hampshire: Excavations 1981-85," 64-65; fig. 22, no. 12.

58 The medieval horse and its equipment c.1150-c.1450. Medieval finds from excavations in London 5, ed. John Clark (New edition, First published 1995, London: H.M.S.O.; Woodbridge: Boydell Press, 2004 [1995]): 89.

59 Mark Redknap, "Ivories from medieval Wales: contexts and afterlives," Sculpture Journal 23(1) (2014): 69. ${ }^{60}$ John Baker, "Harness pendants and the rise of armory," in People, texts and artefacts: cultural transmission in the medieval Norman worlds, ed. David Bates, Edoardo D'Angelo and Elisabeth M. C. van Houts (London: Institute of Historical Research, 2017), 41.

61 Alison R. Goodall, "Non-ferrous metals," in David Austin, Acts of perception, a study of Barnard Castle in Teesdale, 2 volumes, Architectural and Archaeological Society of Durham and Northumberland Research Report 6 (London: English Heritage, 2007), 525; fig. 11.2.4, no. 41.
} 
An earlier terminus ante quem from overseas comes from Burg Isenberg near Hattingen in Nordrhein-Westfalen, Germany, which was destroyed in $1225 .{ }^{62}$ An early thirteenth-century date corresponds well with both the form's probable inspiration from shields and the earliest phases at Odiham from 1207 onwards.

Finally, a snaffle bit was found through metal-detecting (as part of the site investigations) in the field to the east of the castle ${ }^{63}$ (Fig. 6). Although Stoodley ${ }^{64}$ compared this bit with medieval bits classified by Ward Perkins ${ }^{65}$ it is clearly a more recent full-cheek snaffle with twisted mouth (Fig. 5e). The delicacy of finish, plus the "O" shaped loop and the minimal number of twists in the mouthpiece links suggests a modern date (medieval cheekpieces having more of a D-shaped loop); in the late nineteenth century similar examples are documented by Latchford. ${ }^{66}$

In summary, rejecting the snaffle bit but proposing a harness pendant argues for the reappraisal of groups of equestrian equipment even from relatively recent excavations. The small group from the 1981-85 excavations at Odiham may be compared with the far more extensive finds from Ludgershall Castle which include five harness pendants, sixteen spurs, over forty horseshoes, over sixty horseshoe nails, a snaffle bit, a curb bit, and numerous harness buckles and fittings ${ }^{67}$. As noted, the extent and location of investigations at Odiham are probably behind such a discrepancy. We will therefore turn our attention to the wider landscape and evidence derived from the Portable Antiquities Scheme (PAS) database. ${ }^{68}$

\section{E. Evidence from the wider environs, including the deer park area}

Within the deer park area, the only objects traced through the PAS database are four thirteenth- to fourteenth-century coins. ${ }^{69}$ This relative dearth has been observed in other small hunting parks and may relate to a lack of artefacts otherwise introduced onto field systems through manuring of occupational waste (Laura Burnett pers. comm.). Relevant material traced on the PAS database, and set out in detail below, is generally found to the south of the castle, with the exception of a singular harness pendant near Colt Hill (Fig. 6).

Artefacts recorded through the PAS are often decorative as most material reported to it is by metal-detector users who often discriminate against ironwork when searching. Further to the single non-ferrous object noted from the castle excavations, a further four pendants from horse harnesses have been recorded. Potentially the oldest example was found close to Colt Hill (Figs. 1 \& 6). It is circular, shallowly convex and plain (PAS SUR-8E0D0B) (Fig. 7a). Being so common, the form (Krabath Variente 4000) is difficult to address typologically,

${ }^{62}$ Stefan Krabath, Die hoch- und spätmittelalterlichen Buntmetallfunde nördlich der Alpen, 2 volumes (Rahden: Marie Leidorf, 2001), 642; cat. 3254.

63 Taken to be SU727518.

${ }^{64}$ Stoodley, "Metalwork," 68.

65 Ward Perkins, London Museum: Medieval catalogue, 80.

${ }^{66}$ Benjamin Latchford, The loriner : opinions and observations on bridle-bits and the suitable bitting of borses, with illustrations (London: Nichols, Son, \& Co., 1871), fig. 2.

${ }^{67}$ Paul H. Robinson and Nick Griffiths, "The copper alloy objects," in Ludgershall Castle, ed. Peter Ellis, 124-37, 125, 137-142, 152-155, 229.

68 The Portable Antiquities Scheme has been in existence since 1997, with a Finds Liaison Officer covering Hampshire since 1999. Its database therefore represents a key development with which to explore the landscape since the castle excavations took place: https:// finds.org.uk/database/, accessed February 8, 2021.

${ }^{69}$ A penny of Henry III (1248-1250; PAS SUR-DAA944); a penny of Edward III (1344-1377; PAS HAMP-FF5641); a penny and halfpenny of Edward IV (1461-1483; respectively, PAS SUR-1007C1 and HESH-6B84B6). 
and it is hard to say how long undecorated examples endured. Certainly, circular pendants are well attested at an early date in iconographic representations (from the second half of the eleventh century), while a comparable example was found at Newgate Street in London in association with late twelfth- to early thirteenth-century pottery. ${ }^{70} \mathrm{It}$ is therefore plausible that this pendant could be contemporary with the earliest phases of activity at Odiham Castle.

Three further pendants have been recorded from south of the castle (Fig. 6). Potentially the oldest of these is a pendant bell (PAS SUR-339E64), probably from use on harness (Fig. $7 b)$. The particular form, with a relatively long stem and four folded lobes creating a flattened globular bell, is known attached to suspension mounts presumably from harness (e.g. PAS LIN-FD3808, SF-D74876; Krabath Variente 4600). Dating evidence for the form centres on the thirteenth century (e.g. from Wolvesey Castle, Winchester ${ }^{71}$ ), but could be slightly earlier. Also noted is a complete set comprising a gilt and enamelled copper-alloy pendant and identical suspension mount, both of elaborate lozenge form with lis decoration (Krabath Variente 2200) (PAS SUR-A1EAA7) (Fig. 7c). Very little dating evidence is forthcoming for small examples of this type, the best coming from a pendant found in London with ceramics dated to the end of the thirteenth century to the first half of the fourteenth century. ${ }^{72}$ Possibly contemporary with the set is a quatrefoil pendant bearing the device of crossed sword and key on a red (Gules) ground, perhaps representing a variation on the arms of the Bishopric of Winchester (PAS SUR-DFDD03) (Fig. 7d). Quatrefoil pendants (Krabath Variente 5100) have been described as a "late development," 73 with, for example, the Holand arms (c. 13081366) borne by a pendant found in Darlington ${ }^{74}$ reinforcing general fourteenth-century dating for the form.

A final three objects, while also made of copper alloy, are equally functional as they are decorative. A damaged and incomplete "harness hook" was recovered, now missing its lower hook (Fig. 7e). A pair of such hooks would have been retained in perforations one at either end of the lower bar of the lower frame of a curb bit. ${ }^{75}$ Read suggested a c. thirteenth- to fifteenth-century date for harness hooks, ${ }^{76}$ but evidence from arms depicted on examples with shield-shaped terminals suggests that the main period of use centres on the later thirteenth and first half of the fourteenth century. A robust gilt copper-alloy strap loop connecting two slightly wider plates (PAS HAMP-CBEF93) is an object type connected to harness hooks as such strap loops were looped around their hook to attach the reins (Fig. 7f); similar loops are extant on a fourteenth-century curb bit held by the Metropolitan Museum of $\mathrm{Art}^{77}$, with examples known in both iron and copper alloy from earlier. Nearest to the castle a copper-alloy buckle with integral plate with a loop at each end was found (PAS SUR53F297) (Fig. 7g).

\footnotetext{
${ }^{70}$ Nick Griffiths, "Harness pendants and associated fittings," in The medieval horse and its equipment, ed. Clark, 64-65; fig. 47, no. 57.

${ }^{71}$ David A. Hinton, "Harness pendants and swivels," in Object and economy in medieval Winchester, ed. Martin Biddle, Winchester Studies 7.ii (Oxford: Clarendon Press, 1990), 1052; fig. 337, no. 3932.

${ }^{72}$ Griffiths, "Harness pendants and associated fittings," 67-68; fig. 50, no. 70.

${ }^{73}$ Steven Ashley, Medieval armorial borse furniture in Norfolk, East Anglian Archaeology 101 (Dereham: Norfolk Museums and Archaeology Service, 2002), 23.

${ }^{74}$ Krabath, Die hoch- und spätmittelalterlichen Buntmetallfunde, 642; cat. 3278.

75 John Clark, "Curbing horsepower: the archaeology of curb bits in medieval England - and elsewhere," in The horse in premodern European culture, ed. Anastasija Ropa and Timothy Dawson, Studies in Medieval and Early Modern Culture 70 (Berlin: de Gruyter, 2019), 180-181; note 18.

${ }^{76}$ Brian Read, Hooked-clasps and eyes : a classification and catalogue of sharp-or blunt-hooked clasps and miscellaneous objects with hooks, eyes, loops, rings or toggles (Langport: Portcullis Publishing, 2008), 215-216.

77 Wolfgang Gaitzsch, "Ein westeuropäisches Pferdegeschirr des späten 13. Jahrhunderts aus Pergamon,” Istanbuler Mitteilungen 37 (1987): 37, taf. 64.3.
} 


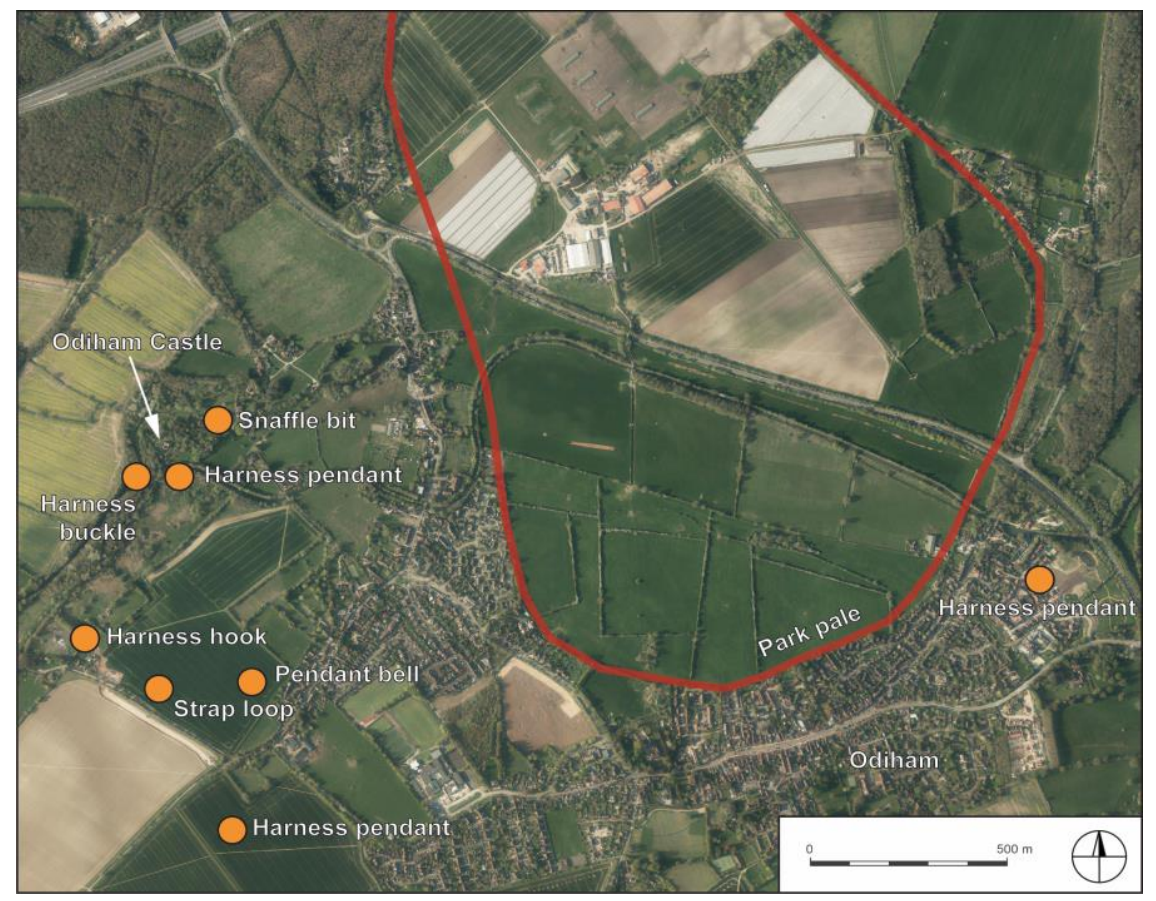

Fig. 6. Map of area around Odiham Castle showing the location of finds discussed here. (Aerial photograph supplied by Edina Digimap, (C) Getmapping Plc')
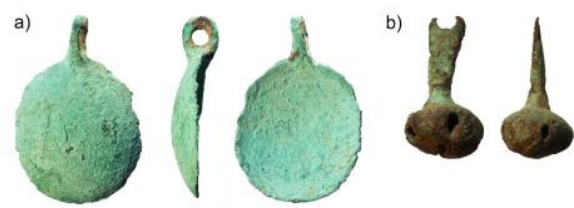

e)

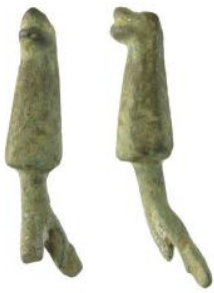

f)

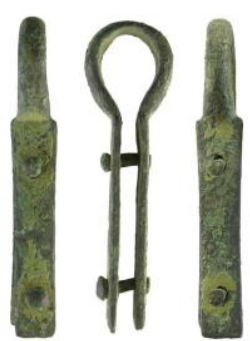

c)
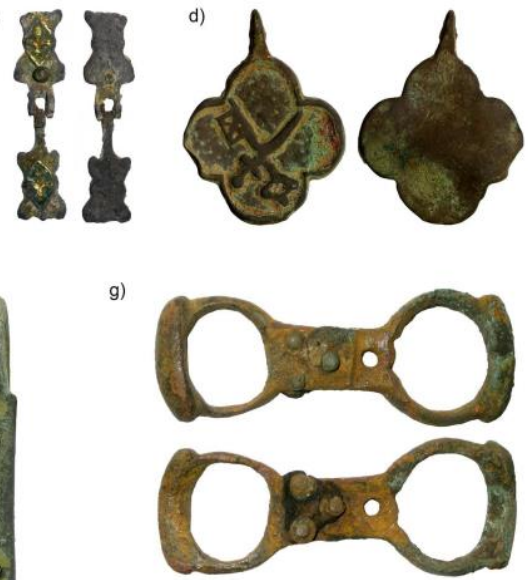

Fig. 7. Equine artefacts from the wider environs of Odiham Castle (courtesy of the

Portable Antiquities Scheme): a-d) harness pendants (where b) pendent bell);

e) harness hook; f) strap loop, probably for a rein; g) double-ended harness buckle/junction. 
The function of this buckle form is unproven, but it has long been suggested to be part of a harness, ${ }^{78}$ allowing tensioning, and attachment by buckling at one end. The best dating evidence for the type comes from London, where an example was found with ceramics dated to the end of the thirteenth century to the first half of the fourteenth century; ${ }^{79}$ iron examples offer similar dating evidence.

In sum, the relative sparseness of equestrian equipment from the immediate area of the castle can now be redressed by a wider analysis of the castle environs and hunting landscape. However, only one relevant find from near Colt Hill and none from within the deer park gives cause for reflection, especially as most of the relevant material comes from the area to the south of the castle. This may relate to local landholders restricting metal-detecting activity, and modern development around the park's southern edge, as well as historic factors, while the land south of the castle has been searched far more actively. Combining the excavated data with that from the PAS provides a richer picture of the equine landscape around Odiham Castle, drawing out evidence for riding horses, including those equipped for hunting and decorated for display. Such horses may be seen in the spur, through evidence for the use of curb bits (provided by the harness hook and strap loop), and through the decorative harness pendants. Chronologically, the whole medieval floruit of the area is plausibly evidenced, from its start in the early thirteenth century, and with a possible focus of activity between c. 1250 1400. Evidence for horse conformation from the artefactual material is sadly limited, especially when the snaffle bit is dismissed, and little can be made of a single horseshoe. That noted, the shoe in question is particularly small for its time.

\section{F. Discussion}

The archaeological evidence from Odiham is a prime example of the power and potential of our integrated, interdisciplinary approach to the study of medieval horses. On their own, each of these strands of evidence (historical, zooarchaeological and artefactual) suggest varying levels of importance of horses at Odiham, each missing key pieces of the story without the others. While the zooarchaeological evidence remains fairly typical of the period, the lack of horse remains belies the unique role that Odiham played within the royal stud network of medieval England. Together, both the historical and physical evidence suggest that no adult warhorses were present (or died) at Odiham in any significant numbers, yet the site was arguably crucial to maintaining a supply of royal warhorses. Though the historical record does not indicate the qualities which were desirable for a warhorse, from the material culture found at Odiham, we get the sense of horses rather smaller than contemporary assemblages would dictate, which is similarly reflected in the zooarchaeological evidence from Odiham and across England. Size clearly was not the most important trait under consideration, despite the modern perception of massive destriers dominating the medieval battlefield.

Furthermore, this integrated approach emphasises the significance of scale when considering the medieval warhorse. Evidence from Odiham Castle itself is sparse across all materials considered, yet when we expand our analysis to include the wider landscape, more nuanced interpretation of the role that horses played here is achievable. In fact, while we might imagine a strong association between royal castles and warhorses, it might be that

\footnotetext{
78 As well as often having mixed metal components - a trait often observed on equestrian equipment its frames are formally similar to items used with harness, such as a possible breast-band buckle which combines a buckle with a pendant suspension mount (PAS NMS-784F84), as at Caherduggan, Co. Cork (Karen Schousboe (ed.), “A peytrel from Caherduggan near Cork,” Medieval Histories 11(2) (2012): 10-11). ${ }^{79}$ Geoff Egan and Frances Pritchard, Dress accessories c $1150-c 1450$. Medieval Finds from Excavations in London 3, New edition (2002), reprinted 2008. First published 1991 (London: H.M.S.O.; Woodbridge: Boydell Press, 2008 [1991]), 108, 110; fig. 70, no. 488.
} 
castles are the last place we would find surviving physical evidence of these horses themselves. Instead, what Odiham shows us from a zooarchaeological perspective, is that the horses dying in/near castles are more likely to be domestic horses used in the daily activities of the site. To overcome this bias in the faunal record, it is essential that we distinguish between military and domestic horses, not just from the bones themselves, but from their wider contexts. This is something that can only be achieved through a combination of interconnected morphological and historical research. In the same vein, if horses were not being ridden in large numbers at places like Odiham, where the focus was on the foundational training of young horses, then characteristic artefacts associated with riding will not be found. And while the wooden structures associated with horses (both studs and domestic stables) are unlikely to leave a trace, an examination of the historical documents allows us to explore these aspects of equine management. By combining new state-of-the-art methodologies with traditional historical and archaeological methods, our interdisciplinary approach therefore generates novel interpretations of the medieval warhorse, with the capacity to challenge historical narratives and create new chronologies and understandings.

\section{Acknowledgements}

This research was funded by the Arts and Humanities Research Council, UK (AH/S000380/1). We would like to acknowledge the help and contributions of the Hampshire Field Club and the Portable Antiquities Scheme for permissions to use images and radiocarbon dates. Particular thanks are owed to David Allen (Hampshire Field Club), who retains a strong interest in Odiham, having jointly supervised its excavation in the 1980s. For discussing the artefacts found at the castle and in the wider landscape, Robert Webley would like to thank John Clark (Curator Emeritus, Museum of London) and Laura Burnett (University of Exeter). Helene Benkert was supported by a College of Humanities $\mathrm{PhD}$ Studentship (University of Exeter).

\section{References}

Allen, David, and Nick Stoodley. "Odiham Castle, Hampshire: Excavations 1981-85." Proc. Hampshire Field Club Archaeol. Soc. 65 (2010): 23-101.

Ashley, Steven. Medieval armorial horse furniture in Norfolk. East Anglian Archaeology 101. Dereham: Norfolk Museums and Archaeology Service, 2002.

Ayton, Andrew. Knights and Warhorses: Military Service and the English Aristocracy Under Edward III. Woodbridge: Boydell \& Brewer, 1999.

Baker, John. "Harness pendants and the rise of armory." In People, texts and artefacts: cultural transmission in the medieval Norman worlds, ed. David Bates, Edoardo D'Angelo and Elisabeth M. C. van Houts, 17-46. London: Institute of Historical Research, 2017.

Bayliss, Alex, Peter Marshall, Michael W. Dee, Michael Friedrich, Timothy J. Heaton, and Lukas Wacker, "IntCal20 Tree Rings: An Archaeological Swot Analysis." Radiocarbon 62 (4) (2020): 1045-78.

Bartosiewicz, László, and Gábor Bartosiewicz. "Bamboo Spine’ in a Migration Period Horse from Hungary." Journal of Archaeological Science 29(8) (2002): 819-30.

Bendrey, Robin. "New Methods for the Identification of Evidence for Bitting on Horse Remains from Archaeological Sites." Journal of Archaeological Science 34(7) (2007): 1036-50.

Boniface, Katrin. "Bread for my Horses." In The Horse in Premodern European Culture, ed. Anastasija Ropa and Timothy Dawson, 161-173. Berlin: De Gruyter, 2019.

Brown, Graham. "Odiham Castle, Hampshire." Series AI/17. English Heritage Archaeological Investigation Report, 2004.

Busby, Debbie, and Catrin Rutland. The Horse. A Natural History. Brighton: Ivy Press, 2019. 
Clark, John. "Horseshoes." In The medieval horse and its equipment c.1150-c.1450. Medieval finds from excavations in London 5, ed. John Clark, 75-123. New edition (2004). First published 1995, London: H.M.S.O.; Woodbridge: Boydell Press, 2004 [1995].

- "Curbing horsepower: the archaeology of curb bits in medieval England - and elsewhere." In The horse in premodern European culture, ed. Anastasija Ropa and Timothy Dawson, Studies in Medieval and Early Modern Culture 70, 177-92. Berlin: de Gruyter, 2019.

- ed. The medieval horse and its equipment c.1150-c.1450. Medieval finds from excavations in London 5, New edition (2004). First published 1995, London: H.M.S.O.; Woodbridge: Boydell Press, 2004 [1995].

Davis, Ralph H. C. The Medieval Warhorse: Origin, Development and Redevelopment. London: Thames and Hudson, 1989.

Dietz, Olof and Bernhard Huskamp. Handbuch Pferdepraxis. Stuttgart: Enke Verlag, 2006.

Edwards, Peter, Karl A. E. Enenkel, and Elspeth Graham. The Horse as Cultural Icon: The Real and the Symbolic Horse in the Early Modern World. Intersections, Volume 18. Leiden and Boston: Brill, 2011.

Egan, Geoff, and Frances Pritchard. Dress accessories c $1150-c 1450$. Medieval Finds from Excavations in London 3, New edition (2002), reprinted 2008. First published 1991, London: H.M.S.O.; Woodbridge: Boydell Press, 2008 [1991].

Ekdahl, Sven. "Horses and Crossbows: Two Important Warfare Advantages of the Teutonic Order in Prussia." The Military Orders 2 (1998): 119-51.

Ellis, Blanche M. A. "Spurs and spur fitting." In The medieval horse and its equipment c.1150-c.1450. Medieval finds from excavations in London 5, ed. John Clark, 124-56. New edition (2004). First published 1995, London: H.M.S.O.; Woodbridge: Boydell Press, 2004 [1995].

Ellis, Peter, ed. Ludgershall Castle: a report on the excavations by Peter Addyman 1964-1972. Wiltshire Archaeological and Natural History Society monographs 2. Devizes: Wiltshire Archaeological and Natural History Society, 2000.

Forgeng, Jeffrey L. The Book of Horsemanship by Duarte I of Portugal (translation). Woodbridge: Boydell Press, 2016.

Gaitzsch, Wolfgang. "Ein westeuropäisches Pferdegeschirr des späten 13. Jahrhunderts aus Pergamon." Istanbuler Mitteilungen 37 (1987): 219-56.

Gladitz, Charles. Horse Breeding in the Medieval World. Dublin and Portland: Four Courts Press, 1997.

Goodall, Alison R. "Non-ferrous metals." In D. Austin, Acts of perception, a study of Barnard Castle in Teesdale, 2 volumes. Architectural and Archaeological Society of Durham and Northumberland Research Report 6, 520-28. London: English Heritage, 2007.

Green, Judith A. "The Great Roll of the Pipe for the 31 Year of the Reign of Henry I, Michaelmas 1130." Pipe Roll Society New Series 57 (2012): 29.

Griffiths, Nick. "Harness pendants and associated fittings." In The medieval horse and its equipment c.1150-c.1450. Medieval finds from excavations in London 5, ed. John Clark, 61-71. New edition (2004). First published 1995, London: H.M.S.O.; Woodbridge: Boydell Press, 2004 [1995].

Hamilton-Dyer, Sheila. “Animal Bone.” In David Allen and Nick Stoodley, "Odiham Castle, Hampshire: Excavations 1981-85.” Proc. Hampshire Field Club Archaeol. Soc. 65 (2010): 75 98.

Hanley, Catherine. Louis: The French Prince Who Invaded England. New Haven: Yale University Press, 2016.

Hardy, Thomas Duffus. Rotuli Litterarum Clausarum in Turri Londinensi Asservati: 1224-1227. London: G. Eyre and A. Spottiswoode, 1833: 1-585. 
Hawkes, John W., and Michael J. Heaton. Closed-Shaft Garderobe and Associated Medieval Structures at Jennings Yard, Windsor, Berkshire. Wessex Archaeology Reports, No. 3. Salisbury: Trust for Wessex Archaeology, 1993.

Hintz, H. F. "Mineral requirements of the horse: A historical perspective." Proceedings of short course on equine nutrition. Kentucky Equine Research, 1996.

Hewitt, H. J. The Horse in Medieval England. London: J. A. Allen and Co., 1983.

Hinton, David A. "Harness pendants and swivels." In Object and economy in medieval Winchester, ed. Martin Biddle, Winchester Studies 7.ii, 1047-53. Oxford: Clarendon Press, 1990.

Hyland, Ann. The Medieval Warhorse: From Byzantium to the Crusades. Stroud: Sutton, 1994.

Jobst, Jennifer. "Practical Advice on Equine Care from Jordanus Rufus, c. 1250 CE." In The Materiality of the Horse, ed. Miriam A. Bibby and Brian G. Scott, 37-69. Budapest: Trivent Publishing, 2020.

Kiesewalter, Ludwig. Skelettmessungen Am Pferde: Als Beitrag Zur Theoret. Grundlage Der Beurteilungslebre Des Pferdes. Leipzig: Druck v. G. Reusche, 1888.

King, Melissa R. "Principles and Application of Hydrotherapy for Equine Athletes." Vet Clin North Am Equine Pract. April 32(1) (2016): 115-126.

Krabath, Stefan. Die hoch- und spätmittelalterlichen Buntmetallfunde nördlich der Alpen, 2 volumes. Rahden: Marie Leidorf, 2001.

Latchford, Benjamin. The loriner: opinions and observations on bridle-bits and the suitable bitting of horses, with illustrations. London: Nichols, Son, \& Co., 1871.

Latham, R. E. Revised Medieval Latin Word-List from British and Irish Sources. London: Oxford University Press, 1965.

MacNeill, Tom. "The iron nails." In Ludgershall Castle: a report on the excavations by Peter Addyman 1964-1972, ed. Peter Ellis, 229-32. Wiltshire Archaeological and Natural History Society monographs 2. Devizes: Wiltshire Archaeological and Natural History Society, 2000.

Marković, Nemanja, Maciej Janeczek, Darko Marinković, Oliver Stevanović, Nikola Krstić, Katarina Petrujkić, and Ružica Trailović. "Paleopathological and Radiological Examination of the Avar Period Horse Bones from Central Balkans (Serbia)." Med. Weter. 71(10) (2017): 619-25.

Morillo, Stephen. "The 'Age of Cavalry' Revisited." In The Circle of War in the Middle Ages: Essays on Medieval Military and Naval History, ed. Donald J. Kagay and L. J. Andrew Villalon, 45-58. Woodbridge: Boydell, 1999.

Page, William, ed. A History of the County of Buckingham: Volume 2. London: A. Constable, 1908.

Pilliner, Sarah. Horse Nutrition and Feeding. Oxford: Blackwell Scientific Publications, 1992.

Prestwich, Michael. "Big and Beautiful'. Destriers in Edward I's Armies." In Military Communities in Late Medieval England: Essays in Honour of Andrew Ayton, ed. Gary Paul Baker, Craig Lambert, and David Simpkin, 1-14. Woodbridge: The Boydell Press, 2018).

Read, Brian. Hooked-clasps and eyes: a classification and catalogue of sharp-or blunt-hooked clasps and miscellaneous objects with hooks, eyes, loops, rings or toggles. Langport: Portcullis Publishing, 2008.

Redknap, Mark. "Ivories from medieval Wales: contexts and afterlives." Sculpture Journal 23(1) (2014): 65-80.

Robinson, Paul H., and Nick Griffiths. "The copper alloy objects." In: Ludgershall Castle: a report on the excavations by Peter Addyman 1964-1972, ed. Peter Ellis, 124-37. Wiltshire Archaeological and Natural History Society monographs 2. Devizes: Wiltshire Archaeological and Natural History Society, 2000.

Schousboe, Karen, ed. “A peytrel from Caherduggan near Cork.” Medieval Histories 11(2) (2012): 9-11.

Sidnell, Philip. Warhorse: Cavalry in Ancient Warfare. London: Hambledon Continuum, 2006. 
Stoodley, Nick. "Metalwork." In David Allen and Nick Stoodley, "Odiham Castle, Hampshire: Excavations 1981-85." Proc. Hampsbire Field Club Archaeol. Soc. 65 (2010): 63-70.

Thomas, Richard, Matilda Holmes, James Morris, and Emily Abrehart. "The Brede of Good \& Strong Horsis': Zooarchaeological Evidence for Size Change in Horses from Early Modern London." Post-Medieval Archaeology 52(2) (2018): 224-38.

Thomas, Richard, and Martin Lacock. "Food for the Dogs? The Consumption of Horseflesh at Dudley Castle in the Eighteenth Century." Environmental Archaeology 5 (2000): 83-91.

Ward Perkins, John. London Museum: Medieval catalogue. London: HMSO, 1967 [1940].

White, Lynn Townsend. Medieval Technology and Social Change. Oxford: Oxford University Press, 1964.

Wilkinson, Louise J.The Housebold Roll of Eleanor de Montfort, Countess of Leicester and Pembroke, 1265, British Library Additional MS 8877. The Pipe Roll Society New Series Lxiii. Woodbridge: The Boydell Press, 2020. 